\title{
Establishment versus Newcomers, Critical versus Administrative?
}

\author{
Sketching the structure of the Swedish field of media and \\ communication studies
}

\author{
Johan Lindell
}

Department of Informatics and Media, Uppsala University, Sweden

\begin{abstract}
The status of the field of media and communication studies has been debated globally and domestically. This study covers virtually all agents $(\mathrm{N}=254)$ in the Swedish field of media and communication studies and draws on Pierre Bourdieu's sociology of science to uncover the main hierarchies in the field. The study focuses on two main divisions. Like in most fields, the most prevalent division is found between the field's incumbents and the challengers/newcomers. A parallel, albeit less prevalent, division is an ontoepistemological one - a variant of the old cleavage between "critical" and "administrative" research. The field's power elite is almost exclusively male, and connected to the field's pioneering institutions.
\end{abstract}

Keywords: sociology of science, field theory, media and communication studies, multiple correspondence analysis, academia

\section{Introduction}

Media and communication scholars have always tried to make sense of their discipline (e.g., Budd \& Ruben, 1972; Carlsson, 2003a; Littlejohn, 1982; Lundgren, 2011; see also Qiu \& Fuchs, 2018). In recent decades, the exercise of turning inward to critically reflect on our own discipline seems to have gained traction. Questions have ranged from inquiries into the topography of communication theory (Craig, 1999; 2015), to what it is that holds the discipline together (Anderson \& Baym, 2004; Waisbord, 2019), to identifying canonic texts (Katz et al., 2003), to mapping citations patterns between journals and subfields (Freelon, 2013). Recent contributions ask whether our scholarship is "too white" and too dominated by males (Chakravartty et al., 2018), or too tied to the Global North (Demeter, 2019a; 2019b; Wiedemann \& Meyen, 2016). The answers suggest that media and communication scholars are caught up in a hyper-specialised "post-discipline" (Waisbord, 2019) dominated by males in the Global North and held together not by common

Lindell, J. (2020). Establishment versus newcomers, critical versus administrative? Sketching the structure of the Swedish field of media and communication studies. Nordicom Review, 41(2), 109-125. https://doi.org/10.2478/nor-2020-0009 
onto-epistemological grounds or objects of study, but by administrative apparatuses such as journals and conferences.

Taking these concerns further, Wiedemann and Meyen (2016) and Demeter (2019a; $2019 b$ ) applied Pierre Bourdieu's sociology of science and cultural production to generate closer looks at the discipline as a social field with particular hierarchies and divisions. This shift in focus from discipline to social field has proven a valuable exercise in reflexive sociology and for moving the field forward in a productive manner. The problem at hand thus concerns the social conditions under which science is produced, and the potential field-internal obstacles to the pursuit of understanding and explaining media and communication. The debate, however, has mainly revolved around the structure of a global field of media and communication scholarship. While the status of the discipline in Sweden has been discussed (e.g., Andersson \& Fornäs, 2010; Bolin, 2010; Carlsson, 2003a) there is to date no systematic study of the contemporary structure of the field.

By adopting a field theoretical perspective, this study ventures further into the study of a field within fields (Bourdieu \& Wacquant, 1992; Fligstein \& McAdam, 2012) - the Swedish field of media and communication studies (henceforth MCS). The contribution is two-fold. First, insights are generated on the social conditions of a field within the field. While the global approaches of Wiedemann and Meyer (2016), Chakravartty and colleagues (2018), and Demeter (2019a; 2019b) have generated important insights on recruitment to top-level positions, and inequalities in voice and visibility, they naturally overlook the struggles that agents are involved with on an everyday, domestic basis. Second, the methodological-theoretical programme of Bourdieu via multiple correspondence analysis (henceforth MCA) - which has hitherto been applied to study academia and the literary field (Bourdieu, 1984/1988, 1999; Sapiro, 2002), the journalistic field (Hovden, 2008), the cinematic field (Duval, 2016), and the field of television production (Lindell et al., 2020) - contributes to the sociology of cultural production more generally.

By applying MCA to study the field of Swedish MCS (N=254), I set out to answer the following research questions:

1. What are the main divisions in the Swedish field of MCS?

2. How are gender differences articulated in terms of the distribution of social resources?

3. What characterises the field's power elite?

\section{Science of science: A field theoretical approach to academia}

It is not uncommon for social scientists to sociologise themselves and scientific production. It was, for instance, studies on the production of knowledge - as embedded in socio-technical systems - that foregrounded the formation of Actor-Network-Theory (Latour \& Woolgar, 1986). Both Karl Mannheim and Michel Foucault emphasised the connection between truth, knowledge, and power (Goldman, 1994). A related approach is Bourdieu's theory of fields - particularly the way it has been applied to the academic field itself (Bourdieu, 1975; 1984/1988). Like other key figures in the sociology of knowledge production, Bourdieu contends that science, like other fields of cultural production, is conducted in contexts ridden with power struggle: "the 'pure' of even the 'purest' science is a social field like any other, with its distribution of power and 
its monopolies, its struggles and strategies, interests and profits" (Bourdieu, 1975: 19). Academic life thus involves struggles over limited resources (or capital), recognition, and who holds the legitimate view of the social world. Bourdieu brings to the table a theoretical-methodological programme to close in on such struggles (as done in Homo Academicus [Bourdieu, 1984/1988]), and that is what sets him apart from related sociologies of knowledge production. Understanding knowledge production via Bourdieu entails a move away from the hagiographic notion found in certain interpretations of the Kuhnian theory of paradigm shifts (Kuhn, 1962), positing that scientific endeavour takes place in a market of ideas where the best - that is, most truthful - researchers come out on top (Bourdieu, 1975).

Social fields are often divided between incumbents and challengers (Fligstein \& McAdam, 2012). Fields, and the struggles and divisions in them, tend, however, to be multidimensional. Those who "have reached the top of the great scientific bureaucracies" - such as Paul Lazarsfeld and the Columbia Bureau of Applied Social Research in the middle of the last century - constitute incumbent actors in the social scientific field (Bourdieu, 1975: 21). Yet, in order for their victory to be considered "the victory of science", their onto-epistemological vision (in this case, the use of statistical research presented in reports that appealed to audiences and funders outside academia) would have to prevail in the field, as such (Bourdieu, 1975: 21). This, of course, never happened. We should thus expect of a field of knowledge production to be divided not only in terms of incumbents/seniority on the one hand, and challengers/juniority on the other, but also alongside onto-epistemological lines where struggles over the legitimate view of the social world play out. In relation to the field of MCS, the history of the disputes between so-called "critical" versus "administrative" research strands (Katz \& Katz, 2016; Lazarsfeld, 1941), the diverse topography of communication theory (Craig, 1999; 2015), and the observation on hyper-specialisation and fragmentation (Waisbord, 2019) testify to this point.

Against this backdrop, one would expect the field of MCS to be divided first, and most importantly, between dominating and dominated agents - the incumbents versus the challengers, old versus young, professors versus $\mathrm{PhD}$ students. Previous research on fields of cultural production tend to identify a second division between "pure" and "impure" production (Duval, 2016; Lindell et al., 2020). This is a division regarding the identity and ideology of practice amongst cultural producers (between those who "produce for producers" and seek recognition from peers, and those seeking recognition externally from stakeholders outside the field). Bourdieu went as far as to argue that "the scientific field functions exactly as a highly autonomous artistic field" (1975: 24). In our case, a second key division would describe disagreements on the legitimate view on the social world and on how to best go about the study of media and communication. The history of the field of MCS suggests that this would be a division between what is usually described as critical and administrative research (Katz \& Katz, 2016; Lazarsfeld, 1941). This captures a generic division between critical/Marxist versus functionalist epistemologies, and in some respects, between qualitative and quantitative researchers, as well as differences in prioritising either field-internal research problems or problems that are shared with outside stakeholders. Historically, such divisions are epitomised in Theodor Adorno's Marxist critiques of mass culture and Paul Lazarsfeld's applied statistics on public opinion, advertisement, and media effects (Lazarsfeld, 1941). 
From Bourdieu's sociology of science, a number of insights emerge. As media and communication scholars, we are invested and believe in the struggles of the field and we adopt the field's practical rationality or common sense (Bourdieu, 1980/1990). This manifests in the common pursuit of understanding and explaining media and communication, and the subsequent communication of such understandings and explanations to peers (primarily via publications) and other stakeholders (e.g., the public, the political field). The "most scandalous offence" to the decorum of the field, to paraphrase Broady (2002: 383), is thus not debating the value of this or that perspective, but rather questioning the very pursuit of scientifically understanding and explaining media and communication. Commonalities have to be in place in order for a field to exist despite internal disagreements (Broady, 2002). A field, furthermore, exists only insofar as it is autonomous - if the above commonalities are specific to a given field. While related fields such as sociology, political science, and film studies all overlap with the field of MCS in some respects, they are either broader or narrower in their focus. Neither do such neighbouring, and sometimes overlapping, fields share the organisational vehicles nor internal governance units (Fligstein \& McAdam, 2012), which I will describe shortly.

Before deploying Bourdieu's analytical programme on the field of Swedish MCS, one must ask if MCS is a social field in the first place, and what previous struggles revolved around it (Broady, 2002). Given the above discussion, it is reasonable to suggest that we are, in fact, dealing with a field with its own common sense, stakes, investments, and autonomy. With Fligstein and McAdam (2012), we can further corroborate the statement. Fields tend to come into existence via 1) state facilitation, 2) the mobilisation of social actors with a common goal, 3 ) settlement of the field's order by key social actors, and 4) internal governance units securing the reproduction of the field (Fligstein \& McAdam, 2012). While this is not the place to chart the emergence and historical trajectory of the field, a brief (and limited) historical excursus is required to consolidate the view of Swedish MCS as a social field.

In the 1960s, mass media became a buzzword in Sweden (Hyvönen et al., 2018). The Social Democrats (who had been in power since 1936) and the prime minister himself - Tage Erlander - identified the need for systematic studies of the mass media (for instance, the decline in newspaper readership) for policy purposes (Hyvönen et al., 2018; cf. Weibull, 2015). The state commissioned a number of investigations on both the media landscape and the principles for institutionalisation of an academic field dedicated to the study of mass media. Stig Hadenius (a historian and political scientist) and Kjell Nowak (a behavioural scientist) became key actors facilitating such institutionalisation. Both became two of the field's first incumbent agents (Hadenius became the first professor of journalism and Nowak became a professor of mass media, both at Stockholm University) (Hyvönen et al., 2018; see also Carlsson, 2007).

Understanding media in the 1960s, Hyvönen and colleagues contend, was a "tug-ofwar between the Nowakian behavioural research ideal and ideological critical left-wingopinion" (2018: 93), where the latter mainly consisted of popular science debate books and journals (Hyvönen, 2015). In a sense, then, the old disputes between administrative and critical research described above echoed in the Swedish context. In the institutionalisation of Swedish media research, the former came out on top, and Jörgen Westerståhl (a political scientist at the University of Gothenburg) could subsequently categorise media research into A- and B-leagues, where the former constituted American-inspired 
media-effects research (Hyvönen, 2015; cf. Weibull, 2015). This strand of research was to be prioritised when institutionalising and funding the field. The latter (the B league) became a catch-all term for other types of media research (Hyvönen et al., 2018). A softer version of this division echoed more than four decades later (Esaiasson, 2003). The struggle between the American-inspired mass media research and alternative, often Marxist or humanistic perspectives, is a case in point regarding the struggles over the legitimate view of the social world amongst agents in the field (Bourdieu, 1975). This is a division that tends to exist alongside a generic hierarchy between seniority/incumbents and juniority/challengers. While the counter-pole to Westerståhl's "A-league" initially was confined to critical public opinion, it gradually gained momentum in the field itself. In a 2010 introspection on the state of the field, Andersson and Fornäs contended, however, that "culturally oriented" perspectives (a broad and largely undefined category describing a combination of qualitative, critical research on everyday life) were still underrepresented in Swedish media research. In response, Bolin (2010) disagreed and presented his own institution (Södertörn University), as well as the departments in Karlstad and Malmö, as examples where critical and culturally oriented media research was carried out. It is likely that Swedish media and communication scholars today would agree with Bolin. The question is whether humanistic or critical researchers and social science media researchers still are "working in entire[ly] different worlds" (Hyvönen et al., 2018: 91).

During its institutionalisation between the 1970s and 1990s, the field gradually matured, and a number of internal governance units emerged (cf. Carlsson, 2003b). The main internal governance units (Fligstein \& McAdam, 2012) are, of course, the educational institutions offering doctoral programmes in MCS since the 1990s. The doctoral programme harbours institutional rites where newcomers are consecrated by the incumbents. Another internal governance unit is Nordicom, an independent, nonprofit research centre that was formed at the University of Gothenburg in the 1970s. Adding to the list - the Nordic media research conference (NordMedia) has been held every second year since 1973, and the Swedish Foundation for Media Research, founded in 1977 , is today an administrative vehicle and online platform securing the reproduction of the field by holding national meetings, publishing blog posts by agents in the field, and granting awards and travelling funds to doctoral students.

Concluding reflections of an introspecting anthology published in the early 2000s was that the field had embraced its diverse nature (Carlsson, 2003a) but that the cleavage between culturally oriented media research and strategic communication (PR) would persist or even widen, not least because departments sought to niche themselves and find their own identities in the field (Jansson, 2003).

While this study is unable to fully grasp all the dynamics presented in this section, we are, nonetheless, able to close in on key manifestations of the hierarchies outlined above.

\section{Data and method}

\section{A half prosopography}

The purpose here is to the study the contemporary structure of the Swedish field of MCS. To do so, I draw on French, or Bourdieusian, prosopography and MCA (Broady, 2002; Rossier, 2019). While most Bourdieusian studies rely on self-reports, the pros- 
opographic approach combines data gathered from public sources such as libraries and archives with self-reports (such as information on social trajectories of agents.). Bourdieu's (1984/1988) Homo Academicus and Sapiro's (2002) study of the French literary field are examples of the approach. The obvious advantage is the focus upon "objective" properties and not relying solely on self-reports. This study draws on the full population of agents in the field of Swedish MCS $(\mathrm{N}=254)$ as found in public registers: university websites, Diva, Libris, Google Scholar, and other archives. As such, the material used primarily consists of digital, so-called "found data" (Bruhn Jensen, 2010), which is why the present study is only a "half" prosopography. Ideally, the study would combine the prosopographic, archival data with a survey and interviews capturing agents' social origins and various position-takings (Broady, 2002). In Homo Academicus, Bourdieu emphasised the difficulty for a social scientist in accessing such data, since a survey on family histories, salaries, and position-takings of one's colleagues could be interpreted as creating a "sectarian and inquisitional police file" (Bourdieu, 1984/1988: 39). The kind of science of science undertaken here is challenging also because it involves the attempt to "exoticize the domestic" (Bourdieu, 1984/1988: xi) by turning scientific instruments onto science itself and, in effect, onto oneself. In the spirit of transparency and reflexive sociology (Bourdieu \& Wacquant, 1992), I have therefore indicated my own position in the field in the results section (Figure 2).

\section{Material, measurements, and data collection}

Data was collected on virtually all agents in the Swedish field of MCS in February 2020. The study includes all Swedish media and communication institutions with more than one person holding a $\mathrm{PhD}$. The data includes staff at the following academic positions: PhD student, post-doctoral researcher/researcher, senior lecturer/assistant professor, associate professor/docent, and professor. Teaching (e.g., "amanuens" and "universitetsadjunkt") and administrative staff were not included in the study.

Nine variables were used to sketch the structure of the field of Swedish MCS. The study set out to capture the positions of agents in the field and, in effect, to study the field's hierarchies. To do so, the study design relied in part on Demeter's (2018) application of Bourdieu's forms of capital (Bourdieu, 1986) to the field of MCS, and in part on Craig's $(1999 ; 2015)$ and Waisbord's (2019) mapping of the communication theoretical terrain of the field and arguments on hyper-specialisation.

Seven out of the nine variables capture various field-specific capitals - both symbolic and material - that can be acquired or accumulated; these can be classified as "found data" (Bruhn Jensen, 2010). University websites were used to disclose 1) academic position (having or not having a $\mathrm{PhD}$ ), and 2) university affiliation (all Swedish institutions conducting research and teaching in MCS with more than one staff member holding a $\mathrm{PhD}$ ). The latter variable was divided into four categories; old universities, old/pioneering universities, new universities, and university colleges. While the $\mathrm{PhD}$ degree captures an academic/cultural capital, the institutional affiliation taps into symbolic capital, since the prestige of institutions - both their positions in the field of MCS (such as the field's pioneering institutions in Stockholm and Gothenburg) and in the broader educational field (the old universities in Lund and Uppsala) - may "trickle down" onto 
their employees (Bourdieu, 1984/1988). Yearly reports from Riksbankens Jubileumsfond [The Bank of Sweden Tercentenary Foundation] and an archive provided by The Swedish Research Council - two of the biggest and most prestigious research foundations in Sweden - were used to disclose accepted research project proposals during the last 18 years (variables 3 and 4). By virtue of granting their recipients both salaries and research time, and internal recognition, these variables constitute both field-specific economic capital and symbolic capital (Demeter, 2018). The public databases Diva and Libris, Google Scholar, and university websites were used in complimentary fashion in order to count the number of published journal articles (variable 5) and monographs (not including research reports) (variable 6). Google Scholar was used to access agent's $\mathrm{H}$-indexes (variable 7). These three variables are additional parts of a field-specific symbolic capital (Demeter, 2018).

In order to also account for agents' positions in the communication theoretical terrain (which helped shed light on the onto-epistemological divisions and the dynamics of the autonomy/heteronomy of various sections of the field), two "made" variables (cf. Bruhn Jensen, 2010) were created. Samples of research output and self-presentations on university websites (when available) were analysed. In the first variable - "Sub-field" - each agent was categorised in one of the following sub-fields: 1) journalism studies, 2) cultural studies, 3) media history, 4) strategic communication/organisational communication, 5) political communication, and 6) a blend of the above or an interdisciplinary approach (which captured those transcending the borders of two or more sub-fields). While this constitutes a rough categorisation, it will suffice to understand the broader divisions in the relatively small field of Swedish MCS. Using a more detailed categorisation, for instance the over twenty sub-divisions of the International Communication Association would 1) not be statistically feasible, since the twenty modalities would skew the contribution to the total inertia of the model, and 2) not reflect the actual terrain of the Swedish field of MCS (where, for instance, health communication and visual communication are marginalised).

For the second variable - "Communication theoretical approach" - each agents' main communication theoretical approach was classified according to Craig's (1999; 2015) seven traditions in communication theory. For instance, agents with a sociopsychological communication theoretical approach frame communication as a problem of influence (which is usually to be measured with quantitative methods), whereas a semiotic approach focuses upon meaning and signs (almost exclusively by studying media texts with qualitative methods) (Craig, 1999; 2015). All but one tradition (the cybernetic tradition, which in Sweden is confined to disciplines such as Information Systems and Computer Science) were represented as a main outlook. Some agents can (and do), of course, criss-cross between various theoretical views on communication. This study accounts, however, only for the main tradition that an agent relies upon. Taken together, the variables measuring sub-field and communication theoretical approach allow - in part because they are proxies for research methods used and objects of study, and autonomy/heteronomy - closing in on whether historical disputes (between what has been described as administrative and critical research) still divide the field.

"Sex" (male/female) and the original "institutional affiliation" and "academic position" variables were projected as supplementary, passive points in the space. Since MCA is sensitive to outliers (categories holding less than $5 \%$ of the observations) the 
institutions at Halmstad University, Linköping University, Linnaeus University, and Gävle University - all with relatively small media and communication departments were combined into one category. Table A1 (Appendix) presents a full disclosure of the variables used and their data sources.

\section{Bourdieu quantifying Bourdieu: Multiple Correspondence Analysis}

MCA is an exploratory statistical technique that extracts structures from a number of qualitative (nominal and ordinal) variables. These structures, or dimensions, are visualised in a two-dimensional space where both individual agents and the categories of the variables are given coordinates depending on their relation to the overarching dimensions. Distances between individuals or variable categories indicate social distances (Hjellbrekke, 2018). Bourdieu favoured MCA because it corresponded with the openended, relational, multivariate thinking of field theory (Bourdieu \& Wacquant, 1992; Duval, 2018; Lebaron, 2009). In order to sketch the structure of the Swedish field of MCS, the nine variables presented above were included in an MCA.

\section{Limitations}

MCA creates imperfect representations of fields (Duval, 2018). The statistical representation of the field of MCS presented here should be viewed for what it is - an impressionistic snapshot. This study is concerned with the field as it was crystallised in a set of digital properties in February 2020. The study is thus confined to the struggles leading up to the early spring of 2020. It goes without saying that fields change (oftentimes slowly, but in small fields sometimes more quickly - for instance if an institution is able to recruit many senior staff members from other institutions, or if the only established senior colleague at a small department leaves).

Additional limitations include the fact that not all field-specific resources were accounted for (e.g., Demeter, 2018), particularly certain economic (salaries) and social capitals (Who knows and works with who? Who has been chair of which conference division and member of which editorial board? etc.). Book chapters and conference presentations, as well as international visits, were left out - focus was put on monographs and journal articles. No account was taken in regards to which publisher agents have published with. The social origins and trajectories of the agents were not included for reasons stated above. Lastly, although most variables were recorded "objective properties", human fallacy in terms of coding and errors in databases or websites may have impacted the results.

\section{Results and analysis}

The structure of the field

The structure of the scientific field at any given moment is defined by the state of the power distribution between the protagonists in the struggle (agents or institutions), i.e. by the structure of the distribution of the specific capital, the result of previous struggles which is objectified in institutions and dispositions and commands the strategies and objective chances of the different agents or institutions in the present struggles. (Bourdieu, 1975: 27) 
Turning to the first research question - What are the main divisions in the Swedish field of MCS? - Figure 1 shows two of the extracted structures, or dimensions, that the MCA produced from the nine active variables presented in the previous section. The second dimension resembled the first (the factorial plane of dimension one and two retains the "horseshoe effect", which indicates uni-dimensionality [Hjellbrekke, 2018: 96]). As such, focus is here put on dimensions one and three, which together explain 72 per cent of the variation among the variables (see Appendix for details on eigenvalues and contributions of variables and modalities/categories to the dimensions).

Figure 1. The Swedish field of MCS - MCA, axis 1 and 3

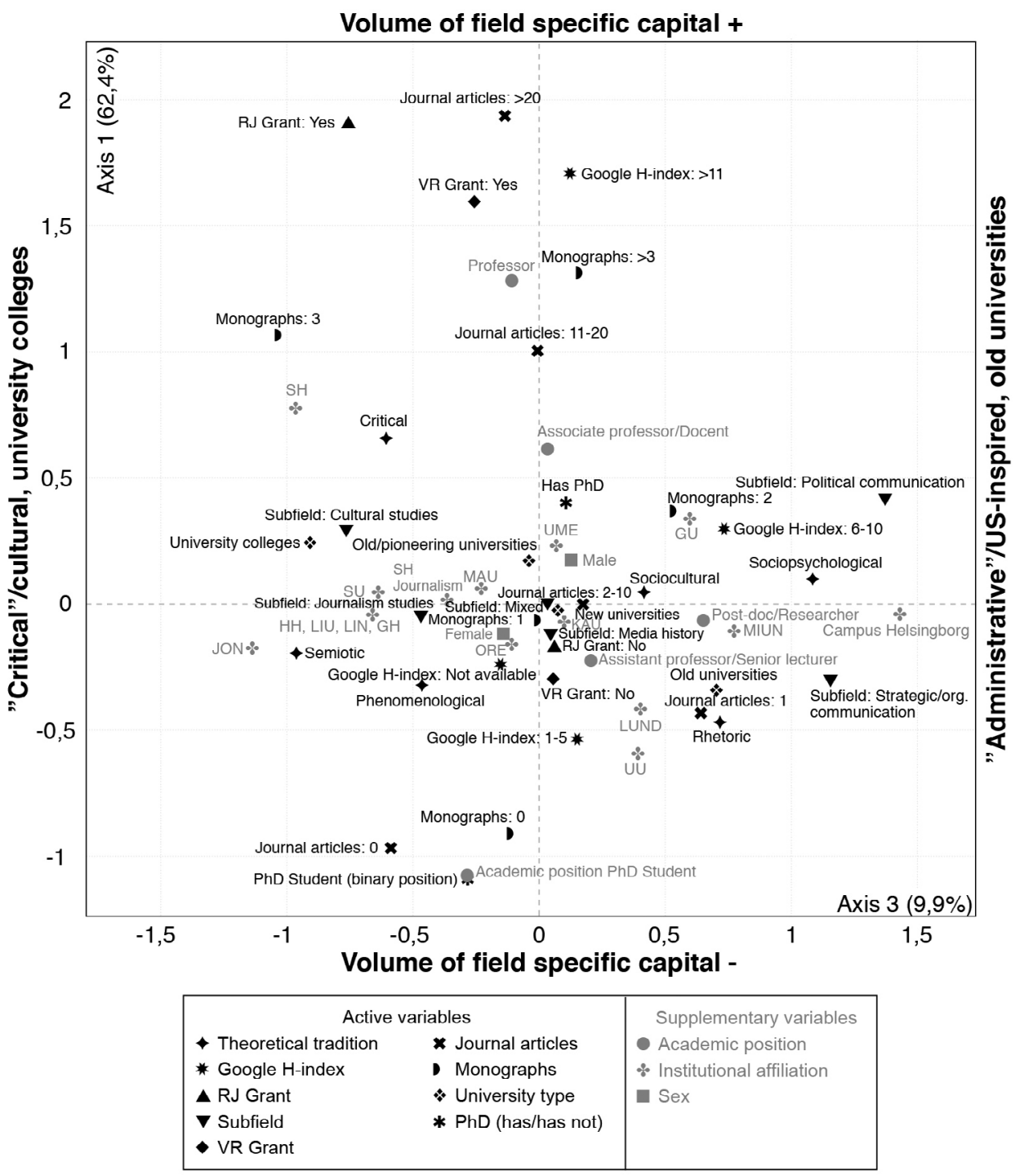

The vertical dimension explains 62 per cent of the variation among the variables and is, accordingly, by far the most important one. The VR-grant and the number of published journal articles and monographs are the most important active variables in this dimension 
(Table A4, Appendix). The dimension represents a division where consecrated agents (those holding a $\mathrm{PhD}$ ) are pitted against $\mathrm{PhD}$ students; where beneficiaries of research grants stand against those without external research funding; and where the publication elite stand against those who have published less or nothing. The vertical dimension describes, in other words, a hierarchy separating an incumbency (top) from challengers and newcomers (bottom), and the volumes of field-specific capital (in academic/cultural, symbolic, and economic forms). Such a separation is found in most fields (Fligstein $\&$ McAdam, 2012). Doing research, writing monographs and (successful) research applications, publishing in journals, and writing promotional applications take both effort and time. As such, this dimension emphasises the fact that fields tend to be timeeconomies (Bourdieu, 1984/1988). Those in the upper echelons of the field possess the social resources and scientific authority required to "influence the way in which [other] agents allocate their time" (Bourdieu, 1984/1988: 98). Compared to assistant professors/ senior lecturers - the incumbency (primarily professors with research grants and many publications) tend to have more time to engage in the activities required to reach their positions in the first place, and they manage other agents' time (not least by directing research at their institutions and by supervising PhD students).

The horizontal dimension explains 10 per cent of the variation among the variables and can be approached as a contemporary variant of what has been described as the historical "tug-of-war" between "Nowakian behavioural research" and "critical left-wing opinion" (Hyvönen et al., 2018: 93; Hyvönen, 2015), or (more recently) between the field's "normal science" and "culturally oriented" media research (Andersson \& Fornäs, 2010; Bolin, 2010; cf. Kuhn, 1962). This dimension also taps into the historical divisions between critical and administrative research (Lazarsfeld, 1941).

Two variables are particularly important to this dimension: the agents' communication theoretical traditions and their sub-fields (See table A4, Appendix). To the right in the map we find agents in a contemporary variant of administrative research - that rely on American sociopsychological traditions (cf. Craig, 1999) and that tend to focus on media effects, influence, and public opinion (often with statistical methods). These agents tend to be active within the sub-fields of strategic/organisational communication and political communication. Projecting all the institutions as passive points in the space, we find that the Strategic Communication Department at Campus Helsingborg (Lund University) and the MCS institutions at Mid Sweden University and the University of Gothenburg are drawn to this pole. Towards the other pole we find a "European" MCS consisting of agents conducting (mostly qualitative) media research or cultural studies from critical and semiotic views on communication. MCS at Södertörn University (not the separate journalism department at the same institution) and Jönköping University stand out in this respect. Karlstad University and Örebro University are the institutions most balanced on both dimensions.

The answer to the question of whether agents in different poles along the second, horizontal dimension continue to live in "entire[ly] different worlds" (Hyvönen et al., 2018: 91) requires some nuance. By virtue of agents "playing the same game" and competing for the same symbolic and material resources, they do live in the same world - but in different parts of it. The distance between factions of the field can be discussed in terms of non-communication between different institutions and that agents are active in different sub-fields, publish in sub-field-specific journals, attend different conferences, and 
address media and communication problems in different, sometimes conflicting, ways. These oppositions are illustrated by Craig's ideal typical position-takings of researchers in various communication theoretical traditions: for a critical scholar, sociopsychological approaches "reflects ideologies of individualism [and] instrumentalism", whereas critical theory, in the eyes of the sociopsychological researcher, "confuses facts and values" (Craig, 1999: 134). A semiotician argues that a sociopsychological researcher's so-called media effects are in fact "internal properties of sign systems", whereas a sociopsychological researcher holds that semiotics "fails to explain the factors that influence the production [and] interpretation of messages" (Craig, 1999: 134).

To some extent, the horizontal dimension also describes a tension between heteronomous and autonomous poles where research is either supposed to be valuable to stakeholders outside the field, or if recognition is mainly sought from peers, inside the (sub-)field (cf. Bourdieu, 1984/1988). One may argue that it is agents in the right side of the space that are richest in external prestige - researchers in strategic and organisational communication are often dealing with "practical" problems that matter to companies, organisations, and the media industry. In some cases, there is an epistemological overlap in that these agents adopt the problems posed by the media industry. One may think of a political communication scholar studying the effects of news consumption on political knowledge who is regularly invited as an expert in the media. Or, the strategic communication researcher who is a consultant on the side.

Taken together, elements of the historical opposition between administrative and critical media research (Lazarsfeld, 1941) of the global field of MCS is reproduced in the Swedish context. I note, however, that this division accounts for 10 per cent of the variation in the space, which means that differences between agents are much better explained by their placement along the incumbency-challenger axis. It should also be noted that while certain strands of administrative research may hold more external prestige because of epistemological overlaps with stakeholders outside the field, they do not necessarily have less internal prestige than agents tending towards critical strands. Historically, American-inspired mass communication research constituted the field's incumbency (Hyvönen et al., 2018). This balance may, however, have tilted.

A key internal debate on the field has revolved around the status of culturally oriented media research - whether it is marginalised (Andersson \& Fornäs, 2010) or not (Bolin, 2010). In fact, the culturally oriented and critical faction of the field is more represented among the Swedish Research Council's and Riksbankens Jubilieumsfond's beneficiaries, and over half of the field's professors rely on either critical, semiotic, or sociocultural perspectives. The picture painted here thus aligns with Bolin's argument that "culturally oriented media research is far from marginalized" (2010: 6). Westerståhl's A- and B-leagues of media research is no longer an adequate classification. Södertörn University, for instance - which Bolin (2010) himself used as an example - is found, along with the critical view on media and communication, towards the top-left of the space, where parts the field's incumbency is located.

This observation also makes for an argument that the field of Swedish MCS is not homologous to the wider educational field in Sweden. In the latter, old universities wield the most symbolic capital and recruit top-performing students from socially privileged backgrounds (Börjesson, 2016; Börjesson \& Broady, 2016). In the Swedish field of MCS, however, the universities at Lund and Uppsala do not hold the most field-specific 
capital. This has generated the situation where the agents with some of the most scientific authority and internal recognition in the field of MCS teach students with low or medium status (in terms of admittance thresholds), and where smaller and less-established MCS departments, such as the institution of Informatics and Media at Uppsala University, teach the most prestigious students (the undergraduate programme in MCS at Uppsala University is the most popular MCS education in Sweden). ${ }^{1}$ While prospective media and communication students are agents in the educational field, they are unaware of the structures of the specific field in which they are undertaking studies.

\section{A male power elite with roots in the field's pioneering institutions}

I turn now to the second research question, regarding the gendered character of the field (cf. Chakravartty et al., 2018): How are gender differences articulated in terms of the distribution of social resources? Projecting sex as a supplementary variable onto the space representing the Swedish field of MCS suggests, somewhat surprisingly, that the hierarchies explored above do not connect well to differences between male and female agents (Figure 1). Exploring this further, Figure 2 reveals the positions of all agents in the field - that is, their positions in relation to the two axes of differentiation explored above. The colouring of Figure 2 shows the sex of the agents. Although males on average have slightly higher positions, the gender categories are found at less than 0.2 deviations from the centre of the space, which indicates a very weak association (Hjellbrekke, 2018). This small difference is explained in that while there are slightly more women $(n=133 ; 52 \%)$ than men $(n=121 ; 48 \%)$ in the field, males are slightly overrepresented amongst the professors (55\%). Among the beneficiaries of Riksbankes Jubileumsfond, the distribution between males and females is 50/50 but males are overrepresented amongst beneficiaries of the Swedish Research Council (62\% are male). The fact that the hierarchies explored above only marginally affect males and females warrants a closer study of the field's power elite, which brings us to the final research question: What characterises the field's power elite?

The power elite is constituted by the incumbent agents who place highest out of all agents in terms of overall volume of capital on either side of the space (the onto-epistemological dimension). Subsequently, the elites can be divided into three groups: The cultural studies-journalism studies elite consists of Göran Bolin, Monika Djerf-Pierre, and Christian Christensen; André Jansson and Mats Ekström constitute the balanced elite; and finally, the political communication elite is made up of Jesper Strömbäck, Bengt Johansson, and Lars Nord. ${ }^{2}$

Four observations are worth highlighting in regards to the field's elite incumbents. First, all of them are somehow connected to the field's pioneering institutions - JMK (at Stockholm University) or JMG (at the University of Gothenburg). Djerf-Pierre, Strömbäck, Ekström, Johansson, and Christensen are currently affiliated with either of these two institutions. Jansson, Bolin, and Nord are not - but they obtained their PhDs from them. Second, the two poles that make up the onto-epistemological divisions in the field are less diverse amongst the power elite compared to the field as a whole. The incumbents are oriented towards cultural studies (Bolin) and journalism studies (DjerfPierre, Christensen) and political communication (Strömbäck, Johansson, Nord) - and two are "balanced" in terms of the onto-epistemological division (Jansson, Ekström). 
Figure 2. The Swedish field of MCS (individuals) - MCA, axis 1 and 3

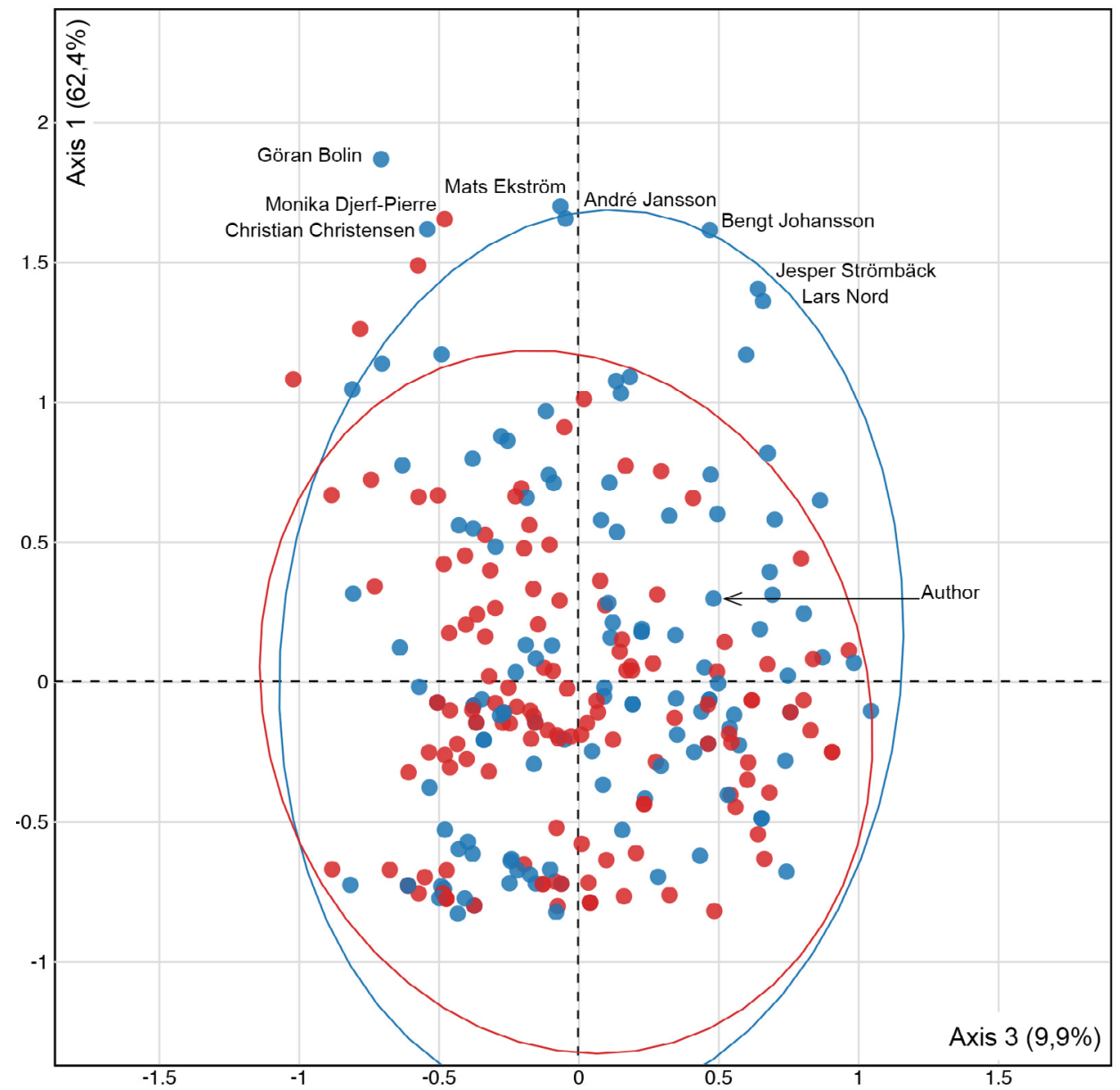

Comment: Red dot $=$ female, blue dot $=$ male

Third, none of the "old universities" (Lund, Uppsala) are represented in the power elite, which is a case in point regarding the absence of a homology between the wider educational field and the field of MCS discussed above. Fourth, and lastly, seven out of eight are male which suggests that while the wider field is structured by gender inequalities only to a limited extent (in terms of distribution of social resources), the power elite remains a male domain, like in many other fields (cf. Göransson, 2007). ${ }^{3}$ Additionally, female agents seem somewhat underrepresented towards the administrative pole where sociopsychological views on communication and political and strategic communication prevail.

\section{Conclusions and ways forward}

This study has focused on two of the main ways in which the Swedish field of MCS is divided. Like most fields, the first and most prevalent division is found between the field's incumbency and its challengers and newcomers. A second division is an onto- 
epistemological one - a variant of the old cleavage between critical and administrative research (Lazarsfeld, 1941) that separates agents and institutions on the basis of differences in theoretical approaches and investments in various sub-fields. This implies that the structure of the field resembles those in other fields of cultural production, where one division separates agents in terms of volumes of field-specific capital, and another on the basis of differences in ideologies of practice (Bourdieu, 1975; Duval, 2016; Hovden, 2008; Lindell et al., 2020; Sapiro, 2002).

While Craig (1999) emphasised epistemological oppositions between various "traditions" in the field, he remained inattentive to the fact that different onto-epistemological approaches may be embedded in broader power dynamics of the social microcosm, wherein both institutions and individual agents oriented towards specific "traditions" struggle over the legitimate view of the social world. Such a focus has allowed this study to identify a key structural transformation since the field's infancy - the social trajectory of "culturally oriented media research" (Andersson \& Fornäs, 2010; Bolin, 2010), which has transformed from Jörgen Westerståhl's "B-league" (Hyvönen et al., 2018) into a dominant force in the field.

It must be noted, however, that the first and the second dimension of the model display a unidimensional tendency describing a generic hierarchy between incumbents and challengers. Together, they explain 77 per cent of the total inertia. In contrast, the onto-epistemological dimension (dimension three, the horizontal axis in Figure 1 and 2 ) - accounts for 10 per cent of the inertia. This implies that we should approach the divisions along the horizontal axis with some caution. Indeed, the results suggest first and foremost that this field is divided between seniors and newcomers, between the publishing and research-grant elite and those without publications or external funding - that is, between those with low and high volumes of field-specific capital. One's position in this main hierarchy is heavily dependent upon investment and time. It should come as no surprise that both age and the life stage when the agent entered the field play central roles in positioning agents on this dimension.

If the first and second dimensions deal with time - a requirement for gaining high positions in the field, as well as a resource controlled by the field's incumbents - the third one (the horizontal axis) charts the different mental and physical spaces occupied by the agents. The horizontal axis captures differences in the mental maps used to define what communication is and how to best understand and study media and communication. Additionally, it highlights divergences in the spaces of sub-fields and their adjacent publication venues, as well as the physical locales of institutions and sub-field-specific conferences that different agents visit and feel a belonging to. Future research on various social fields should delve deeper into these time- and space-bound divisions. Time-based questions would include: Who has time to do what? Who controls the time of others? How well is time and investment linked to high positions in a field? Space-based questions include: How spatially divided is the field in question? What characterises the spaces of exclusion and inclusion? A hypothesis for field theory posits that the more autonomous and internally coherent a field is, the less spatially divided it is, in terms of both the mental or conceptual and physical spaces occupied by agents.

Future quantitative research should, furthermore, supplement this study design by accounting for agents' social and educational trajectories, position-takings, and inherited capitals, which would allow further exploration of the dimensionality of the field. 
A good starting point for such an endeavour is found in Demeter's (2018) mapping of various capitals in the field of MCS.

On a broader level, the study has suggested that the Swedish field of MCS is not homologous to the wider Swedish educational field where the "old universities" possess the greatest symbolic capital (Börjesson, 2016; Börjesson \& Broady, 2016). Furthermore, the power elite of the field is almost exclusively male and connected to the field's pioneering institutions in Gothenburg and Stockholm.

The present study is a contribution to the ongoing, global debate on the structure of the field and the status of our discipline (cf. Chakravartty et al., 2018; Demeter, 2018; 2019a; 2019b; Wiedemann \& Meyen, 2016). The study has provided insights into the struggles that media and communication scholars face, directly or indirectly, on an everyday, domestic basis. A call for future studies involves, first, the study of other fields within the global field of MCS. Are MCS fields in South Korea, Norway, the US, and so forth structured in the same way? What are the regional differences and similarities? Second, more research should be carried out on this particular domestic field to cover the blind spots of this study. Such research should especially turn to agents on temporary teaching contracts, the status of agents born outside of Sweden, the various position-takings of agents in the field and, perhaps most importantly, how the structural differences uncovered here play out in practice.

Finally, an obvious question concerns how one, as participant in the field, should make sense of the divisions explored here. Carlsson (2003b), Höijer (2003), and Bolin (2010) called for the field to embrace its diversity. In contrast, political scientist Esaiasson (2003) echoed historical primacy of American-inspired mass communication research. What does this say if not that the answers to the question on how to deal with divisions and diversity in the field are themselves hinged upon the social positions from where they are articulated? For one, it is clear that agents' overall volume of field-specific capital give voice in these matters. Second, more or less innocent everyday slander and degrading of opposing theoretical approaches or choices of study objects highlight that position-takings still play out along an onto-epistemological cleavage. The historical tug-of-war between critical and administrative research has not come to an end.

\section{Notes}

1. This is not an implicit argument about the quality of the educational programmes at the different institutions. It should also be noted that the department at Uppsala University was severely understaffed at the time of data collection. During 2020, the department recruited two senior researchers and one full professor. Had data collection been conducted later during 2020, the position of this institution in the field is likely to have changed.

2. The exact positions of the elite incumbents along the vertical axis should be approached with some caution. Since MCA uses ordinal and nominal data, it underestimates some fine-grained differences in terms of, for instance, number of publications. For example, had the analysis been able to account for the exact number of publications (rather than categories holding various ranges of numbers of publications), Jesper Strömbäck would be positioned higher in the space.

3. While it is clear that male agents dominate the very top of the space (and potentially the field as such), it should also be noted that the pattern of male overrepresentation holds also if we expand the view and look, for instance, at the agents above 0.1 deviations on axis 1 . Here, 14 out of 19 agents are male.

\section{References}

Anderson, J. A., \& Baym, G. (2004). Philosophies and philosophic issues in communication, 1995-2004. Journal of Communication, 54(4), 581-615. https://doi.org/10.1111/j.1460-2466.2004.tb02647.x 
Andersson, M., \& Fornäs, J. (2010). Mediekulturperspektivets möjligheter: Ett samtal i kulturaliseringens tecken [The possibilities in the term of media culture: A conversation in the spirit of culturalisation]. Nordicom Information, 32(1), 3-22.

Bolin, G. (2010). Medieforskningens möjligheter: Fältdominans, gränsöverskridanden och konsolidering inom medie-och kommunikationsvetenskapen [The possibilities of media research: Field dominance, interdisciplinarity, and consolidation in media and communication studies]. Nordicom Information, 32(4), 3-7.

Bourdieu, P. (1975). The specificity of the scientific field and the social conditions of the progress of reason. Information (International Social Science Council), 14(6), 19-47.

Bourdieu, P. (1986) The forms of capital. In J. G. Richardson (Ed.), Handbook of theory and research for the sociology of education (pp. 241-258). New York: Greenwood Press.

Bourdieu, P. (1988). Homo academicus (P. Collier, Trans.). Stanford: Stanford University Press. (Original work published 1984).

Bourdieu, P. (1990). The logic of practice (R. Nice, Trans.). Stanford: Stanford University Press. (Original work published 1980).

Bourdieu, P. (1999). Une révolution conservatrice dans l'édition [A conservative revolution in publishing]. Actes de La Recherche En Sciences Sociales [Research Acts in Social Sciences], 126(1), 3-28.

Bourdieu, P., \& Wacquant, L. J. (1992). An invitation to reflexive sociology. Chicago: University of Chicago press.

Broady, D. (2002). French prosopography: Definition and suggested readings. Poetics, 30(5-6), 381-385. https://doi.org/10.1016/S0304-422X(02)00031-1

Bruhn Jensen, K. (2010). New media, old methods - Internet methodologies and the online/offline divide. In R. Burnett, C. Consalvo, \& C. Ess (Eds.), The handbook of Internet studies (pp. 43-58). Hoboken, New Jersey: Wiley Blackwell.

Budd, R. W., \& Ruben, B. D. (Eds.) (1972). Approaches to human communication. Rochelle Park, New Jersey: Hayden.

Börjesson, M. (2016). Sociala kartor över utbildningslandskapet: Installationsföreläsning, professuren i utbildningssociologi vid Uppsala universitet, 11 november 2015 [Social maps of the educational landscape: Installation lecture: Professorship in the sociology of education at Uppsala University, 11 November 2015]. Sociologisk forskning, 53(4), 421-436. https://www.jstor.org/stable/24898976

Börjesson, M., \& Broady, D. (2016). Elite strategies in a unified system of higher education: The case of Sweden. L'Annee sociologique, 66(1), 115-146.

Carlsson, U. (Ed.) (2003a). Mångfald i medieforskningen [Diversity in media research]. Gothenburg: Nordicom, University of Gothenburg.

Carlsson, U. (2003b). Några inledande ord [Some introductory words]. In U. Carlsson (Ed.), Mångfald $i$ medieforskningen [Diversity in media research] (pp. 7-10). Gothenburg: Nordicom, University of Gothenburg.

Carlsson, U. (2007). Media and mass communication research past, present and future: Reflections from a Nordic horizon. Nordicom Review, 28, 169-181.

Chakravartty, P., Kuo, R., Grubbs, V., \& McIlwain, C. (2018). \#CommunicationSoWhite. Journal of Communication, 68(2), 254-266. https://doi.org/10.1093/joc/jqy003

Craig, R. T. (1999). Communication theory as a field. Communication theory, 9(2), 119-161. https://doi. org/10.1111/j.1468-2885.1999.tb00355.x

Craig, R. T. (2015). The constitutive metamodel: A 16-year review. Communication Theory, 25(4), 356-374. https://doi.org/10.1111/comt.12076

Demeter, M. (2018). Theorizing international inequalities in communication and media studies: A field theory approach. KOME: An International Journal of Pure Communication Inquiry, 6(2), 92-110. https:www. doi.org/10.17646/KOME.75692.94

Demeter, M. (2019a). The winner takes it all: International inequality in communication and media studies today. Journalism \& Mass Communication Quarterly, 96(1), 37-59. https://doi. org/10.1177/1077699018792270

Demeter, M. (2019b). So Far, Yet So Close: International career paths of communication scholars from the Global South. International Journal of Communication, 13, 578-602.

Duval, J. (2016). Le Cinéma au XXe siècle: Entre loi du marché et règles de l'art [Cinema in the twentieth century: Between market law and rules of the art]. Paris: CNRS editions.

Duval, J. (2018). Correspondence analysis and Bourdieu's approach to statistics. In T. Medvetz, \& J. J. Sallaz (Eds.), The Oxford handbook of Pierre Bourdieu (pp. 512-527). Oxford: Oxford University Press.

Esaiasson, P. (2003). Omedvetna kommunikationsforskare? [Unaware communication researchers?]. In U. Carlsson (Ed.) (2003). Mångfald i medieforskningen [Diversity in media research] (pp. 35-40). Gothenburg: Nordicom, University of Gothenburg.

Fligstein, N., \& McAdam, D. (2012). A theory of fields. Oxford: Oxford University Press. 
Freelon, D. (2013). Co-citation map of 9 comm journals, 2003-2013. Retrieved May 29, 2020, from http:// dfreelon.org/2013/09/05/co-citation-map-of-9-comm-journals-2003-2013/

Goldman, H. (1994). From social theory to sociology of knowledge and back: Karl Mannheim and the sociology of intellectual knowledge production. Sociological Theory, 12(3), 266-278. https://www.doi. org/10.2307/202125

Göransson, A. (Ed.). (2007). Maktens kön [The gender of power]. Stockholm: Nya Doxa.

Hjellbrekke, J. (2018). Multiple correspondence analysis for the social sciences. London: Routledge. https:// doi.org/10.4324/9781315516257

Hovden, J. F. (2008). Profane and sacred: A study of the Norwegian journalistic field. Bergen: The University of Bergen.

Hyvönen, M. (2015). Mediekritik i pocketformat: Massmedieproblem i debattböcker 1965-1975 [Media criticism in pocketbook format 1965-1975]. In M. Hyönen, P. Snickars, \& P. Vesterlund, (Eds.), Massmedieproblem: Mediestudiets formering [Mass media problems: The formation of media studies] (pp. 278-330). Lund, Sweden: Mediehistoria.

Hyvönen, M., Snickars, P., \& Vesterlund, P. (2018). The formation of Swedish media studies, 1960-1980. Media History, 24(1), 86-98. https://doi.org/10.1080/13688804.2016.1270751

Höijer, B. (2003). Mångfald i medievetenskapen [Diversity in media research]. In U. Carlsson (Ed.), Mångfald i medieforskningen [Diversity in media research](pp. 63-70). Gothenburg: Nordicom, University of Gothenburg.

Jansson, A. (2003). Tids nog märker man att man vill göra något eget: Om forskarens självförverkligande och fältets förvandling [Time enough you notice that you want to do something on your own: About the researcher's self-realisation and the field's transformation]. In U. Carlsson (Ed.), Mångfald i medieforskningen [Diversity in media research] (pp. 99-107). Gothenburg: Nordicom, University of Gothenburg.

Katz, E., Durham Peters, J., Liebes, T., \& Orloff, A. (Eds.). (2003). Canonic texts in media research. Cambridge: Polity Press.

Katz, E., \& Katz, R. (2016). Revisiting the origin of the administrative versus critical research debate. Journal of Information Policy, 6(1), 4-12. https://www.doi.org/10.5325/jinfopoli.6.2016.0004

Kuhn, T. (1962). The structure of scientific revolutions. Chicago: University of Chicago Press.

Latour, B., \& Woolgar, S. (1986). Laboratory of life: The construction of scientific facts. Princeton: Princeton University.

Lazarsfeld, P. F. (1941). Remarks on administrative and critical communications research. Zeitschrift für Sozialforschung, 9(1), 2-16. https://doi.org/10.5840/zfs1941912

Lebaron, F. (2009). How Bourdieu "quantified" Bourdieu: The geometric modelling of data. In K. Robson, \& C. Sanders (Eds.), Quantifying theory: Pierre Bourdieu (pp. 11-29). Dordrecht: Springer.

Lindell, J., Jakobsson, P., \& Stiernstedt, F. (2020). The field of television production: Genesis, structure and position-takings. Advance online publication. Poetics. https://doi.org/10.1016/j.poetic.2019.101432

Littlejohn, S. W. (1982). An overview of contributions to human communication theory from other disciplines. In F. E. X. Dance (Ed.), Human communication theory: Comparative essays (pp. 243-285). New York: Harper \& Row.

Lundgren, L. (2011). You know nothing of my work! Tankar om medie- och kommunikationsvetenskapens historia [Thoughts on the history of media and communication science]. Nordicom Information, 11(3), 75-81.

Qui, J. L., \& Fuchs, C. (Eds.) Ferments in the field: The past, present and futures of communication studies [special issue]. Journal of Communication, 68(2), 219-451.

Rossier, T. (2019). Prosopography, networks, life course sequences, and so on: Quantifying with or beyond Bourdieu? Bulletin of Sociological Methodology/Bulletin de Méthodologie Sociologique, 144(1), 6-39. https://doi.org/10.1177/0759106319880148

Sapiro, G. (2002). The structure of the French literary field during the German Occupation (1940-1944): A multiple correspondence analysis. Poetics, 30(5-6), 387-402. https://doi.org/10.1016/S0304$422 \mathrm{X}(02) 00032-3$

Waisbord, S. (2019). Communication: A post-discipline. Cambridge: Polity.

Weibull, L. (2015). Medieämnets etablering i Sverige [The formation of media studies in Sweden]. In M. Hyönen, P. Snickars, \& P. Vesterlund (Eds.), Massmedieproblem: Mediestudiets formering [Mass media problems: The formation of media studies] (pp. 125-163). Lund, Sweden: Mediehistoria.

Wiedemann, T., \& Meyen, M. (2016). Internationalization through Americanization: The expansion of the international communication association's leadership to the world. International Journal of Communication, 10(21), 1489-1509.

Copyright: (C) 2020 The Author(s) and Nordicom. This is an Open Access article distributed under the terms of the Creative Commons Attribution 4.0 International License (CC BY-NC-ND 4.0). 